Научная статья /

Research Article

УДК 821.І6г.2.0

ББК 83.3(4Укр)
ЭТНОКУЛЬТУРНОЕ ПОГРАНИЧЬЕ:

КОНЦЕПТУАЛЬНЫЙ, ТИПОЛОГИЧЕСКИЙ И СИТУАТИВНЫЙ АСПЕКТЫ (ЧУЖОЕИНОЕ-СВОЕ). Статья третья:

(C) 202I г. Ю.Я. Барабаш

Институт мировой литературы им. А.М. Горького

Российской академии наук,

Москва, Россия

Дата поступления статьи: о2 октября 2020 г.

Дата одобрения рецензентами: 25 января 2021 г.

Дата публикации: 25 июня 2021 г.

https://doi.org/IO.22455/2500-4247-202I-6-2-264-303

Аннотация: Заключительная часть триптиха посвящена проблематике украинскоеврейского литературного пограничья. В отличие от двух предыдущих частей, где превалировали геополитический и региональный аспекты (Галичина, Харьков-Донбасс), здесь на первый план выходит пограничье «внутреннее», или, по М. Бахтину, «диалогический контакт между текстами (высказываниями)», что предполагает приоритетную роль синхронического подхода. В качестве семантического и методологического «общего знаменателя» для двух подходов выступает формула диалектической взаимосвязи категорий «Чужое», «Иное», «Свое». Исследование проводится по трем направлениям: І) еврейская тема в украинской литературе как «текст»; акцент - на специфике художественных решений; 2) писатели-евреи в лиминальном литературном пространстве Украины, феномены культурных диффузий и интерференций; 3) украинские писатели еврейского происхождения - социопсихологический вариант этнокультурного пограничья.

Ключевые слова: еврейская тема, «текст», бесконтактный диалог, контактное пограничье, антиимперский выбор, неимперская интеграция, двуединая идентичность.

Информация об авторе: Юрий Яковлевич Барабаш - доктор филологических наук, профессор, главный научный сотрудник, Институт мировой литературы им. А.М. Горького Российской Академии наук, ул. Поварская, д. 25 а, І2Іо69 г. Москва, Россия.

E-mail: barabash.yuri@gmail.com

Для цитирования: Барабаш Ю.Я. Этнокультурное пограничье: Концептуальный, типологический и ситуативный аспекты (Чужое - Иное - Свое). Статья третья // Studia Litterarum. 202I. T. 6, № 2. С. 264-303. https://doi.org/IO.22455/2500-4247-202I-6-2-264-303

\footnotetext{
* Статьи первую и вторую см. в журнале Studia Litterarum: [2; 3].
} 


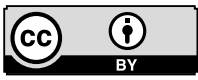

This is an open access article distributed under the Creative Commons Attribution 4.0 International (CC BY 4.0)

Studia Litterarum, vol. 6, no. 2, 202I

\section{ETHNO-CULTURAL BORDERLINE: CONCEPTUAL, TYPOLOGICAL, AND CIRCUMSTANTIAL ASPECTS (ALIEN - OTHER - ONE'S OWN). Third article}

(C) 202I. Yu.Ya. Barabash

\author{
A.M. Gorky Institute of World Literature \\ of the Russian Academy of Sciences, Moscow, Russia \\ Received: October 02, 2020 \\ Approved after reviewing: January 25, 202I \\ Date of publication: June 25, 202I
}

Abstract: The final part of the triptych is devoted to the problematics of Ukrainian-Jewish literary border. Unlike two previous parts, where geoplitical and regional aspects prevailed (Galitchina, Kharkov - Donbass), here the "internal" border is focused on, or, according to M. Bakhtin, "the dialogical contact between texts (statements)" which implies the priority role of the synchronic approach. As a semantic and methodological "common denominator" for two approaches, the formula for the dialectical interconnection of categories "Alien," "Other," "Own" is used. The research is conducted in three directions: $\mathrm{I}$ ) the Jewish theme in Ukrainian literature as the "text;" the accent is put on the specificity of literary solutions; 2) writers-Jews in the liminal literary space of Ukraine, the phenomena of cultural diffusions and interferences; 3) Ukrainian writers of the Jewish origin - sociopsychological version of the ethnocultural border.

Keywords: Jewish theme, "text”, contactless dialogue, contact border, anti-imperial choice, non-imperial integration, two-pronged identity.

Information about the author: Yuri Ya. Barabash, DSc in Philology, Professor, Director of Research, A.M. Gorky Institute of World Literature of the Russian Academy of Sciences, Povarskaya 25 a, I21069 Moscow, Russia.

E-mail: barabash.yuri@gmail.com

For citation: Barabash, Yu.Ya. "Ethno-cultural Borderline: Conceptual, Typological, and Circumstantial Aspects (Alien - Other - One's own). Third article.” Studia Litterarum, 202I, vol. 6, no 2, pp. 264-303. (In Russ.) https://doi.org/I0.22455/2500-4247-202I-6-2-264-303 


\section{Украинско-еврейское литературное пограничье}

В предыдущих двух статьях триптиха проблема этнокультурного пограничья рассматривалась как преимущественно культурологическая, причем с выраженным превалированием регионального ракурса (Галичина, Харьков-Донбасс); это, впрочем, не исключало внимания к «внутреннему» пограничью в рамках отдельных явлений. Применительно к украинскоеврейскому литературному пограничью приоритеты меняются местами, региональный аспект и здесь остается безусловно важным, но превалирует аспект «внутренний», то, что М. Бахтин в своих «Рабочих записях» определял как «диалогический контакт между текстами (высказываниями)» [5, c. 424]. В качестве объединяющего принципа, своего рода семантического и методологического «общего знаменателя» для обоих аспектов выступает формула диалектической взаимосвязи категорий «Чужое», «Иное», «Свое».

Рассмотрение темы в статье проводится по трем направлениям, в увязке с общеукраинским историко-литературным контекстом.

а) Еврейский дискурс в украинской литературе

(«дистанционное», или опосредованное, пограничье,

бесконтактный «диалог»; мотивации,

принципы интерпретации, художественные решения)

Характерная черта ряда исследований, посвященных данной теме, социально-экономический и идеологический крен, в результате чего приводимые примеры из истории украинской литературы воспринимаются скорее как иллюстрации к общетеоретическим положениям, нежели как $x y$ дожественные феномены. Эстетический, поэтологический критерии прак- 
тически отсутствуют, поэтика как система приемов и средств воплощения еврейской темы в художественном тексте, как правило, не рассматривается. Это относится и к работе Г. Грабовича «Еврейская тема в украинской литературе XIX и XX вв.», хотя в целом она, несомненно, выделяется на общем фоне [9].

С учетом сказанного при рассмотрении в данной статье взятых выборочно, без претензии на полноту, с учетом значимости и репрезентативности текстов внимание будет уделено прежде всего художественным решениям.

\section{T. Шевченко. «Гайдамаки» и не только «Гайдамаки»}

Применительно к этой поэме в критической практике в качестве ключевого обычно выступает понятие «стереотип» в его социопсихологическом истолковании. Имеется в виду факт частого, по сути преимущественного использования Шевченко негативных, уничижительных либо презрительных характеристик персонажей-евреев («жидов» ${ }^{I}$ ); хотя у Шевченко есть - немногочисленные, но есть, - примеры объективных, даже сочувственных суждений и оценок.

В принципе понятие «стереотип» надо признать соответствующим реалиям и особенностям национального массового сознания определенной исторической эпохи, не случайно к нему прибегают практически все авторы, исследующие тему. Однако необходимо заметить, что относящийся к ней тот или иной анализируемый объект может рассматриваться не только (а в известном смысле и не столько) на социальноэкономическом и политико-идеологическом уровнях, но также на уровне собственно литературном. И здесь возможно и уместно применение, кроме «стереотипа», понятия литературной традиции как структурно- и смыслообразующего фактора. Эти два понятия представляют собою бинарную недихотомическую систему корреляционного характера. Стереотип рождается в недрах традиции, на основе того или иного повторяющегося элемента, затем, также функционируя в режиме повторяемости,

I B русских переводах этот этноним отсутствует. Между тем в старой украинской (и в других славянских) разговорной, а также и литературной, практике «жид» - нормальная форма, адекватная первичному этнониму (лат. јudaeus, ивр. יהוי - «иудей»), лишенная тех социопсихологических и идеологических наслоений, которые в силу исторических обстоятельств закрепились в русской языковой практике, а в советское время ставшая запрещенной (см.: [8, с. 22I-222]). Впрочем, споры на эту тему не утихают. 
постоянно подпитывая и обогащая традицию, часто сам превращается в своего рода традицию.

Подход Т. Шевченко к еврейской теме, к образу еврея стереотипен в той мере, в какой он отражает исторически сложившееся восприятие этого образа массовым национальным сознанием. Такое восприятие отразилось в фольклоре, в староукраинской литературной традиции. Типологически общие черты образа «жида» - корыстолюбие, жадность, коварство, услужливость по отношению к сильному, в данном случае - к поляку, готовность быть его орудием в деле религиозного и национального угнетения украинского крестьянина; часто еврей предстает в смешном, карикатурном виде, на что обращает внимание И. Франко в своей работе «К истории украинского вертепа XVIII в.» [22, с. I79].

Включением в процесс исследования проблемы такого понятия, как «традиция», акцентируется приоритетный характер литературного подхода к теме перед подходами социально-экономическим и тем более перед идеологическим. В этом плане интерес представляет анализ еврейской составляющей «Гайдамаков» в общем контексте поэмы, на пограничье и во взаимодействии (чаще всего конфликтного характера) с другими компонентами художественного дискурса.

Первая «заявка» на такое пограничье появляется уже в «Интродукции» к поэме: мы узнаем, что польские конфедераты, которые «разбрелись» по Украине,

Сговорились с торгашами,

Чтобы грабить вместе.

Что хотели, то творили,

Церкви оскверняли...

(Пер. А. Твардовского) [32, с. І2I]

Здесь обозначен один из распространенных в украинском массовом сознании эпохи после Брестской унии (I596) и сохранивший свое влияние в XIX в. стереотип, согласно которому хозяйничающая на Украине польская шляхта отдавала православные храмы в аренду своим пособникам - евреям, так что, как рассказывают в «Тарасе Бульбе» прибывшие на Сечь казаки, «если жиду вперед не заплатишь, то и обедни нельзя править» [28, с. 77]. 
Первичная реплика получает развитие в последующих главах поэмы, где еврейский мотив вступает во взаимодействие с другими мотивами, образами, сюжетными ситуациями, авторскими отступлениями. В тексте поэмы складывается «дискурс Лейбы», в основе которого лежит не понятие совокупности и не логика последовательного развития входящих в эту совокупность компонентов, а понятие системы и принцип дополнительности. Структурной единицей повествовательного дискурса выступает пара противоположных, взаимоисключающих, но при этом взаимодополняющих компонентов - бинарных оппозиций.

Лейба-шинкарь, издевающийся над своим батраком, бедным казаком Яремой, и Лейба, унижаемый польскими конфедератами, - одна из таких оппозиций. Другая: Лейба, ради своего спасения дающий конфедератам «наводку» на хранящего общественные деньги церковного старосту и его дочку-красавицу, и тот же Лейба, помогающий (правда, под страхом расправы) Яреме вызволить Оксану из польского плена. И еще оппозиция, характеризующая неоднозначное отношение автора поэмы к его персонажам-евреям - отцу, «чертовой копилке», и к его дочери:

Лейба.

Согнулся дугою,

У постели над светильней

Считает монеты.

А в постели - вся раскрыта

Разметалась, раскидалась,

Темно ей и душно,

Спит тревожно, беспокойно, -

Одинокой тяжко...

Хороша была еврейка,

Что-то шепчет пылко!

$$
\text { [32, C. } 123-\mathrm{I} 24]
$$

На стыковом пограничье между членами этих оппозиций возникает зона эмотивной и семантической напряженности, в которой рождаются новые смыслы, складывающаяся система коммуникативных отношений обретает такие признаки художественного «высказывания», как 
его бинарно-оппозиционная природа, как относительная автономность, членимость и одновременно связанность (когезия) и полнота (когерентность), что дает основание определить еврейский компонент поэмы термином «текст» - систему, предстающую в многомерном пограничном пространстве, в комбинаторике моментов пересечения и взаимодействия (чаще всего конфликтного характера) еврейского «текста» с аналогичными локальными «текстами» - польским, украинским, гайдамацким, авторским.

Что касается отношения автора поэмы к Лейбе и вообще к евреям, то здесь бросается в глаза разброс шевченковских характеристик и оценок, который отражает сложности и зигзаги - на уровне психологии - движения к осознанию «чужого» как «иного», на мировоззренческом уровне - процесса формирования зрелого национального сознания и демократических убеждений, в частности, в еврейском вопросе.

Знаменательным, в определенном смысле итоговым моментом данного процесса стало участие Т. Шевченко в широкой протестной кампании виднейших писателей и ученых России против антисемитских выступлений издателя и редактора журнала «Иллюстрация» В. Зотова. В петербургском журнале «Русский вестник» (I858, т. XVIII, ноябрь, кн. 2) было опубликовано письмо Марка Вовчка (М. Вилинская), Н. Костомарова, П. Кулиша, М. Номиса (М. Симонов) и Т. Шевченко, в котором выражалась солидарность с ранее опубликованными протестами и специально излагался взгляд украинских писателей на проблему [12] ${ }^{2}$.

\section{И. Франко. Парадоксы еврейского дискурса}

В широкой и многоуровневой панораме творческой, научной, общественнно-политической деятельности Ивана Франко, охватывающей его поэзию, прозу, публицистику, эпистолярий, еврейский дискурс предстает как сложная идейно-политическая и духовно-нравственная структура, компоненты которой находятся в динамике амбивалентных, подчас взаимоисключающих, семантических соотношений.

2 В эту пору среди знакомых Т. Шевченко, вернувшегося из ссылки в Петербург, было, как свидетельствуют его письма и «Дневник», немало евреев. Один из них - лечивший поэта еще в его молодые годы доктор Александр Дмитриевич Бланк, дед В.И. Ленина по материнской линии. 
Какие моменты выступают в качестве определяющих для понимания характера и смыслов этих процессов, направленности их векторов?

Тут следует выделить объективный и субъективный факторы. Первый, безусловно, объективный, внеличностный, - особенности исторического развития и геополитического положения Галичины, специфические черты региона как межэтнического и этнокультурного пограничья, важным структурным компонентом которого был еврейский этнос. И. Франко вырос, сформировался и прожил жизнь в среде со значительным еврейским компонентом. Он дружил с евреями-одноклассниками, сначала в сельской школе, затем в дрогобычской так называемой нормальной. Он интересовался - в контексте проблематики украинского национального возрождения и государственности - сионистскими идеями (Т. Герцль, Н. Бирнбаум), переписывался с М. Бубером. Образы евреев, черты еврейской идентичности, внутрисемейные отношения, повседневный быт и традиционный уклад еврейских местечек («штетлов»), роль еврейства в социально-экономических, идейно-политических и культурных процессах, в социалистическом и, позднее, национальном движениях в Галичине - эти аспекты, по объему и значимости которых с И. Франко не может сравниться ни один украинский писатель, составили в его творчестве единый и «сквозной» еврейский дискурс.

Единый, однако не цельный, «сквозной», однако не последовательно прямой. Еврейский дискурс Ивана Франко дуален, парадоксален, зигзагообразен. Вот, к примеру, рассказанная с искренним душевным чувством, словно в pendant к шевченковской «Катерине», трогательная история о судьбе бедной еврейской девушки-служанки, обманутой хозяином, но нашедшей счастье в материнстве (поэма «Сурка» из цикла «Еврейские мелодии»), - а вот публиковавшаяся едва ли не в то же время в журналах «Зеркало» и «Нове зеркало» сатирическая поэма «Швинеделеса Пархенблита путешествие из села Дерихлопа (! - Ю.Б.) в Америку и обратно»; поэма, стилизованная под еврейско-галицкий жаргон, содержит двусмысленные намеки на Талмуд, якобы разрешающий еврею «драть хлопа». Я. Грицак, комментируя эту публикацию, отмечает, что поэма «потрафляла вкусам читательской публики» [Іо, с. 353].

Еще пример: в тех же «Еврейских мелодиях» читаем проникнутые библейским гневом и призывами к отмщению еврейские монологи «Сам- 
батион» («Живе цар Давид наш і бачить / Усі наші кривди й біду»-«Живет наш царь Давид и видит / Все наши кривды и беды» [3I, с. I9]) и «Перья» («O, свідку великої кари, / O, пір’я жидівських перин» - «О, свидетель великой кары, / О, перья еврейских перин!» [3I, с. 20]). Их пафос - осуждение еврейских погромов, прошедших в г88г г. в южных украинских губерниях Российской империи. И вдруг всего через три года - вновь «зигзаг»: в статье «Еврейский вопрос», опубликованной без подписи на первой странице газеты «Діло», И. Франко, возвращаясь к теме погромов, которые, как он опасается, могут, вслед за Россией и Венгрией, произойти и в Галичине, называет в качестве первопричины «деморализующее преобладание еврейского капитала и эксплуатации».

Двойственными предстают образы евреев в крупных прозаических произведениях Ивана Франко. Но здесь они отражают не двойственную позицию автора, а черту характера создаваемого автором персонажа, раскрывают формирующие эту черту обстоятельства.

B Postscriptum ко второй редакции своей повести «Петрии и Довбущуки» И. Франко, отмечает, что стремился показать «попытки вольнодумного движения» в еврейской среде и «раввинские реакции» на них. Центральная фигура этого внутриеврейского, внутриконфессионального остро конфликтного пограничья - Исак Бляйберг. Ему, пострадавшему и едва спасшемуся от грабителей, в трагическую минуту жизни на помощь приходит украинский крестьянин Петрий, складывается другое - позитивное, нравственное -этнокультурное пограничье. Недавний корчмарь осознает внутреннюю потребность перемен в своей судьбе, он выходит на новую дорогу, какой до него не ходил ни один еврей.

Вагман из романа «Перекрестные тропки» - ростовщик, пользующийся в городе и во всем уезде дурной славой «пиявки», человека, который «не чурается самого грязного гешефта». Однако это лишь одна сторона натуры Вагмана и его деятельности. Вагман использует свое хорошее знание законов и еще лучшее - слабостей и уязвимых мест представителей власти, а также немалые финансовые средства, для помощи украинским крестьянам в их судебных тяжбах с «урядниками». Необычная деятельность ростовщика-пиявки объясняется в романе желанием Вагмана мстить власть имущим за гибель сына, случившуюся по их вине, а также страхом перед «пожаром ненависти» к евреям со стороны украинского населения, опасностью погромов. 
В повести «Воа constrictor» и романе «Борислав смеется» евреи-миллионеры Герман Гольдкремер и Леон Гаммершляг, хозяева бориславских нефтяных месторождений, этой «галицкой Калифорнии», изображены беспощадно и жестко, как эксплуататоры украинских рабочих, пролетаризованных крестьян. Многозначительная метафора - на стене в кабинете Гольдкремера висит картина, на которой удав душит попавшую в его засаду газель. Некоторые критики усматривают в позиции автора этих произведений, в его художественной манере следование антисемитским стереотипам. Это поверхностный вывод, вытекающий из отождествления позиций автора и персонажей произведения. На самом деле Франко не ставит перед собою задачу изложения своих взглядов, он стремится по возможности точно, реалистически достоверно - и, признаем, не без натуралистических подробностей - отразить настроения рабочих, их окрашенные обидой и гневом оценки работодателей. Присутствуют ли в этих описаниях некие личностные коннотации, отражающие отношение самого автора к изображаемым конфликтам? Несомненно так, только определяются они не национальным критерием, а симпатиями Франко к идеям социализма (как он их понимал), солидарности трудящихся, гуманистическими принципами.

М. Коцуюбинский. «Он идет»

(Ужас в замкнутом пространстве еврейского местечка)

...Вы и представить себе не можете весь ужас того внутри-снаружи, каким является истинное пространство. Некоторые из теней, напрягаясь в последний раз, делают отчаянное усилие к «бытию в целости и единстве». Ничего не получается.

Анри Мишо. Пространство теней

Вряд ли Анри Мишо читал «образок» М. Коцюбинского «Он идет»; во всяком случае Гастон Башляр, по чьей книге «Поэтика пространства» приводится вынесенная в эпиграф цитата [6, с. І86], трактует ее в связи с сартровской концепцией «неантизации», отнюдь не с черниговским еврейским погромом І905 г.

Но - «бывают странные сближенья»: степень коррелятивности удаленных друг от друга сочинений А. Мишо и М. Коцюбинского такова, что 
кажется, будто первый и впрямь комментирует сочинение второго. Этот жесткий стыковой фронтир между «внутри» и «снаружи» пространства еврейского местечка; эти «отчаянные усилия» его насельников сохраниться «в целости и единстве», но «ничего не получается»; наконец, этот разлитый по всему пространству местечка «ужас», всепроникающий, всепоглощающий, экзистенциальный Ужас...

М. Коцюбинский находится в замкнутом пространстве еврейского местечка, во время погрома, одного из тех, что происходили в 1905 г. в Черниговской губернии и в самом Чернигове. В «образке» это замкнутое пространство взорвано, в местечко врываются враждебные, разрушительные силы:

Словно скотина ревела в загоне или градовая туча мчалась по небу.

Это шел крестный ход.

Тысячи ног били землю, тысячи тел колебали воздух, шелестели на просторе хоругви, и грубыми, нечеловеческими голосами ревели толстые попы, как из бочки, а длинные пряди их волос, развеваясь на ветру, бились о жесткие золотые ризы <...>. Топотали тысячи ног, дышали тысячи грудей, ревели басы и плясали, как безумные, колокола. Большие, средние, маленькие... [3о, с. 204-205].

Это финал повествования, и это начало трагических событий, разворот которых остается за рамками текста и нашего, читательского, ви́дения.

Внимание писателя сосредоточено на предшествующем этапе, отмеченном нарастанием тревоги, ожиданием неотвратимо надвигающейся беды. Ощущение высочайшей степени концентрации эмоциональной напряженности, резкой смены настроений - страха и гнева, паники и надежды достигается М. Коцюбинским за счет использования разнообразной палитры художественных средств. Реалистические детали, отражающие бытовую обстановку «штетла», традиционные привычки, специфические черты поведения, национального характера, местечкового идиш-sleng'a, переплетены с присущими творческой манере М. Коцюбинского приемами импрессионистской поэтики, в которой важнейшая роль принадлежит живому восприятию момента, игре красок, контрастов, светотеней, звуков. «...Разговор становился горячим и бурным, слова гремели, как возы с железом, и белые руки лавочников то и дело мелькали перед рыжими бородами» 
[30, с. 20I] (здесь и ниже курсив мой. - Ю.Б.); «Всюду скрипели железные засовы, бренчали замки и ключи, гремели двери, заслоняя черный зев, и в одно мгновение серые древние стены рынка выбросили вон всех людей» [30, с. 20I]; «Черные кучки понурых, охваченных волнением людей растекались с базара по тесным улочкам, - и на площади стало так пусто и тихо, точно весь гомон жизни обратился вдруг в серый камень» [30, с. 2ог]. В кульминационные моменты импрессионистское начало вступает во взаимодействие с экспрессионистской составляющей, с цветовыми и звуковыми контрастами, придающими картине жутковатый, почти апокалиптический оттенок: «Приближался вечер. Солнце росло, пламенело и медленно опускалось вниз. Красный туман поднимался на западе, и словно кровавые призраки надвигались оттуда на город. Сначала робко, поодиночке, а потом сплошными рядами. Беззвучной процессией прошли они между опустевшими стенами, оставляя на камне горячие красные следы и отражаясь в окнах своими кровавыми лицами. Древние стены дрожали от ужаса всеми своими морщинами, и только красные маки, которые росли вверху по карнизам, приветствовали гостей смехом. А когда солнце село - и пришла ночь, как черная дума земли, красные гости исчезли и местечко совсем замерло» [3о, c. 20I]. Мелькают, словно выхваченные лучом света, искаженные страхом и отчаянием лица: извозчик Иосель «с кнутом в грубых, узловатых руках» [30, с. 20I], он отправляет на своих фургонах убегающих из местечка «пурицев» - купцов, которые побогаче; растрепанная, в одной рубахе, женщина, прижимающая к груди серебряный семисвечник; девушка, мечущаяся между людьми с хорьковой шубой, «своими молящими, почти безумными глазами она сеяла ужас» [3о, с. 203]. Трагическая фигура - старый шойхет (резник птицы и скота в иудейской общине), почитаемый в местечке реб Абрум, в чьем образе словно сконцентрировались страх, вера в чудо, гнев, отчаяние его единоверцев: «За ним кто-то гнался. Он мчался по тесным улицам, месил ногами глубокую пыль, пробегал мимо домов, сворачивал в сторону, и пот заливал ему глаза <... >. Только бы добежать, только бы добежать...» [3о, с. 204].

Бегут все. Лицом к лицу с тысяченогой, несущей смерть толпой, остается одна слепая Эстерка, выплакавшая глаза после гибели в другом погроме двух сыновей. То, что она, слепая, но ясновидящая, предсказала накануне, - гибель детей, опьяневшие от крови звери, мертвые глаза женщин, 
кровь на поповских ризах, - теперь становится жуткой явью. Повествование выходит из профанного пространства провинциального местечка на уровень ветхозаветной мифологии: подобно героине «Книги Есфири», Эстерка (Эсфирь) выступает на защиту своего народа. В ключевой формуле произведения - «Он идет» - открывается неожиданный, более глубокий и более драматичный, чем это кажется местечковому люду, смысл. Для Эстерки, не просто слепой, но ослепленной горем и отчаянием, «Он» - это для нее не сам по себе крестный ход, не ревущие «от полного чрева жирные попы» [30, c. 204], не погромщики, а Тот, рожденный в Назарете, Чьим именем они кощунственно прикрывают свои преступления.

- Слушай, ты, еврейский сын! - кричала она слова, которые оставались у нее в горле. - Ты снова идешь? Ты, отнявший моих детей! Моего Лейбу и моего Хаима. Ты снова благословишь проливать кровь твоего народа!.. Слушай, куда ты идешь, остановись... Хватит крови.. [30, с. 204-205].

...Мы вспоминаем Анри Мишо с его «ужасом пространства».

Микола Бажан. Эхо Умани в большом мире

Детские годы и юность (І9Іо-І92I) Миколы (Николая Платоновича) Бажана прошли в Умани. В эти годы евреи занимали первое место среди представителей других национальностей, населяющих город, - около пятидесяти процентов.

Эхо еврейской Умани стало одним из мотивов творчества М. Бажана, не магистральным, нет, но выраженно личностным. Правда, звучало - и воспринималось критикой - оно в разные периоды и в разных обстоятельствах по-разному. В изданной в 1972 г. книге «Уманские воспоминания» оно вообще не прозвучало, там были стихи о подпольной уманской типографии, в которой в І903 г. печаталась газета «Искра», но не было поэмы «Дебора», посвященной подруге юности поэта Раисе Файнштейн; поэма была опубликована за четыре года до этого в журнале «Вітчизна» и стала поводом для критики автора за, по его горько-шутливому выражению, «украинский буржуазный сионизм»; «Дебора» увидела свет лишь в посмертных изданиях M. Бажана. Поэме «Гетто в Умани» также не нашлось места в этом уманском цикле, как и в 1988 г. в московском однотомнике. 
Поэма «Гетто в Умани» (1929) выдержана в стилевой гамме экспрессионизма, одной из составляющих стиля барокко, черты которого отмечала у М. Бажана критика. Ю. Лавриненко, например, называл раннего Бажана (периода «Расстрелянного возрождения», т. е. І920-х - начала І930-х гг.) «главным и совершенно сознательным архитектором литературного барокко» [16, с. 960]. Профессор Гарвардского университета Омелян Прицак, обосновывая в 1970 г. выдвижение кандидатуры М. Бажана на соискание Нобелевской премии (инициатива не получила развития, в частности, из-за отказа поэта - слишком свежа была в памяти история с «Доктором Живаго»), подчеркивал приверженность М. Бажана традициям украинского барокко «с его богатством гротескных символических деталей, широких метафор, энигматических метонимий» (цит. по: [І5, с. 36]).

Степень сгущенности экпрессионистических средств, насыщенности ими образной системы в поэме чрезвычайно высока. Вот начальные строки:

Пылает земля, пылает ржа и пыль,

Как жар фурункула, как язва трахомы,

И солнце надо всем - как взрыв пятен и стрел,

Как взрыв молчливый и тяжко неподвижный,

Этот маниакальный круг, выплыващий в зенит,

Этот круг, рожденный в огне галлюцинаций...

(Подстрочный перевод мой. - Ю.Б.)

Далее эта линия развивается по нарастающей: «самум небесный», «бездны жара, пропасти молчаливые», «земля сожженная, раскаленная и пряная», «пятнистый тиф отчаянного лета», «лужи живой желчи в пыли».

Узнаваемых черт уманского еврейского мира в поэме минимум, в качестве главного структуро- и смыслообразующего фактора выступает метафорическое начало, оно открывает перед поэтической мыслью многомерное пространство большого мира, в котором эхо Умани едва слышно.

В характерных для стиля поэмы экспрессионистически напряженных контрастах отразилась амбивалентность позиции автора, противоречивый характер движения его мысли. Бажан видит и осознает трагизм исторической судьбы еврейского народа, «старый Сион», священный «одногорбый» холм, ассоциируется у него с библейской Голгофой, это «Гол- 
гофа нации, с огнем вместо креста», оплот ее Веры. В то же время эта вера для автора поэмы - «позор», «трупная яма»», он отвергает «оргазм веры», «оргазм безумства»: «Кричит толпа сторотая и стоглазая, / Словно один эпилептический рот»3. Он призывает еврейство («О, шма Исраэль, шма!» «Внемли, Израэль!») отвергнуть «хасидский Содом», напоминает, что не все идут дороги на «опозоренный Сион». «Пусть горят Сионы!» ${ }^{4}-$ таков финал поэмы.

Поэма подверглась зубодробительной критике. Особенно свирепствовала в те «великопереломные», по выражению Л. Новиченко, рапповская критика, в частности, отличался, как это обычно бывает, «землячок», выходец с Винничины, А. Селивановский, с большевистской прямотой заявивший, что путь М. Бажана «противоположен маршруту социалистической революции» [19, с. 47].

В поэме «Дебора», написанной почти через сорок лет после «Гетто», в ту пору человеческой жизни, когда память все чаще возвращается в молодые годы, «эхо Умани» доминирует. Историко-мифологический еврейский элемент здесь представлен практически лишь ссылкой на имя пророчицы Деборы (Деворы) из ветхозаветной Книги Судей, героической женщины, вдохновительницы борьбы евреев за независимость. Углубления в историю здесь нет, есть реминисценция, подсказывающая читателю параллель между подругой юности М. Бажана Раей Файнштейн, которой посвящена поэма (в посвящении она названа Деборой), и библейской героинейг.

Судьба героини вписана в рамки г920-х гг., в реальный контекст тогдашней Умани - этнического, религиозного, культурного пограничья, в котором еврейский компонент существует вместе и во взаимосвязи с украинским и польским. Рядом высятся православный храм, костел, греко-католический василианский монастырь и синагога, где служит кантором отец Деборы/Раи. В многоуровневом и едином духовном пространстве незримо живут наставления хасидского философа и пророка Баал-Шем-Това и псалмы Григория Сковороды, еврейская молитва Кол Нидрей переплетается

\footnotetext{
3 URL: https://www.litmir.me/br/?b=500II8 (дата обращения: 26.04.202I).

4 Там же.

5 Это исполненная драматизма и романтики история. М. Бажан написал «поэму памяти», он считал, что Рая была расстреляна нацистами в Сухом Яру вместе с тысячами других уманских евреев. Лишь после публикации поэмы он узнал от краеведа и журналиста Н. Комарницкого, что его героиня жива. Сохранилась переписка между ними.
} 
с поминальным казацким плачем слепых кобзарей, вальсы Шопена - с «грозовыми мелодиями» Лысенко. На дощатых подмостках, установленных в костеле, в спектаклях студии Леся Курбаса «Кийдрамте» звучат, под фортепьянный аккомпанемент Раи Файнштейн, шевченковские и пушкинские стихи, Эдип и Шекспир, Тычина, Василь Чумак, русалочьи песни.

«Сливались две реки», объединялись два мира, и к обоим была причастна Дебора.

\section{P.S.: Боль Бабъего Яра}

Название стихотворения М. Бажана «Яр», написанного в г943 г. в только что освобожденном от нацистов Киеве, ориентирует читательское восприятие на еврейскую тему. Между тем ни одного прямого упоминания о евреях в стихотворении нет.

Чем можно объяснить этот факт?

Разумеется, во всяком случае не незнанием. О том, что в Бабьем Яру расстреливают евреев, киевляне знали уже во время трагедии, а после освобождения Киева эти сведения стали общеизвестными.

Возможны разные версии объяснения. Например, субъективно-поэтическая. Стихотворение «Яр» - это мгновенная вспышка, удар боли, момент эмоционального потрясения фактом (обще)человеческой трагедии.

Есть, однако, и другая сторона вопроса. В первоначальном варианте официального заявления Чрезвычайной государственной комиссии о трагедии в Бабьем Яру речь шла о гибели «мирных советских граждан», этой формулой в процессе редактирования текста было заменено слово «евреи». Известно, что в Бабьем Яру в конце сентября - начале октября г94і г. действительно были расстреляны представители разных национальностей, однако абсолютное большинство составляли все-таки евреи (в общей сложности по Бабьему Яру называются цифры от 70 до 200 тыс.). Вряд ли М. Бажан, член ВКП(б), главный редактор фронтовой газеты «За Радянську Україну», мог не знать об этой партийной установке, предвестнице кампании по «борьбе с сионизмом». Нет сомнений, что это была для поэта драматическая душевная коллизия. Поэма «Дебора», написанная в І968 г., хоть и «полуопубликованная», стала для М. Бажана возвращением к «эху Умани», к самому себе. 
b) Писатели-евреи в лиминальном литературном пространстве украины (региональные и временны е варианты пограничья, пограничье «внутреннее», феномены культурных диффузий и интерференций); разнообразие и специфика форм отражения украинской действительности в их творчестве; геополитический фактор и языковые ориентации

\section{Западный регион (Галичина, Волынь)}

Характерная особенность творческих биографий писателей еврейского происхождения, уроженцев этого региона, - их европейская ориентация, выбор в качестве языка творчества официального на тот момент для данной геополитической ситуации (т. е. в условиях Австро-Венгрии либо Польши) языка, немецкого или польского, и, соответственно, включение в австрийский либо польский литературный процесс при сохранении, в разной степени и в разных формах, элементов галицко-волынской украинской составляющей.

В австрийской (немецкоязычной) литературе под этим углом зрения должны быть в первую очередь названы уроженец местечка Черткова (ныне Чортков) на Тернопольщине Карл Эмиль Францоз (г848-1904) и Йозеф Рот (г894, Броды - г939) ${ }^{6}$.

Заметный след в немецкоязычной литературе оставил Александер (Иешаяху) Гранах (г890-І945). Он родился на Станиславщине (ныне Ивано-Франковская область) в бедной еврейской семье, подростком освоил профессию пекаря. Переломным оказалось посещение (то ли в Станиславе, то ли во Львове) еврейского театра: г6-летний А. Гранах, владевший в то время, кроме идиша, только украинским, отправляется сначала в Лондон, там он общается с русскими и еврейскими студентами-анархистами, участвует в любительских спектаклях, затем едет в Вену, где, работая пекарем, играет - на идише - в еврейском театре. Переехав в Берлин, где через некоторое время, фантастическими усилиями освоив немецкий язык, А. Гранах пробивается в труппу возглавляемого Максом Рейнхардтом Немецкого театра. После прихода к власти Гитлера А. Гранах некоторое время, до отъезда в США, живет в Советском Союзе. Актерская карьера А. Гранаха

6 Анализ произведений этих писателей в ракурсе австро-украинского этнокультурного пограничья см.: [2]. 
сложилась успешно, кроме игры в театре, он в г920-I930-е гг. снялся в нескольких десятках фильмов. Одновременно А. Гранаха влечет литературная деятельность, он пишет театральные рецензии, статьи, после смерти Гранаха были опубликованы его книга «писем из изгнания» к Лотте Ливен, подруге юности, и недавно изданный в России роман-автобиография «Вот идет человек» [29], в первой части которого представлены колоритные и достоверные национальные типы, сцены жизни, быта, еврейско-украинских взаимоотношений в галицких местечках и селах, а также в «столице» Галичины - Лемберге/Львове, одном из главных топосов-мифов творчества немецкоязычных писателей - выходцев из этого края.

Свой «миф Львова» есть и у польских писателей того времени. Если у Йозефа Рота этот миф окрашен грустью, ностальгией (в I924 г., когда написан очерк «Лемберг, город», Львов, как и вся Галичина, уже не был австрийским), то доминантой польского мифа был тезис о «вечной польскости» Львова. Ностальгические нотки, проскальзывающие в книге Юзефа Виттлина (г896-I976) «Мой Львов», связаны не с историей и политикой, а с воспоминаниями детства, гимназических лет, проведенных во Львове, куда его еврейская семья переехала из села Дмитрова. У сатирика, куплетиста, журналиста Марьяна Хемара (настояшая фамилия - Хешелес), выходца из состоятельной, известной во Львове еврейской семьи, Львов предстает в ином контексте - смеховом, буффонадном, не лишенном фантасмагорических черт. Объединяет Хемара с Виттлином то, что у них, как, впрочем, и у других польских авторов межвоенной, иногда и более поздней, поры (например, в автобиографическом романе «Высокий замок» Станислава Лема) нет Львова украинского. В атмосфере эйфории по случаю возвращения на "Кresy" - Восточную окраину Речи Посполитой - идея «польскости» Галичины заслоняла историческую и демографическую реальность.

В существенно ином ракурсе предстает проблема мифологизма у Бруно Шульца (г892-I942), самой значительной фигуры польско-еврейско-украинского литературного пограничья. Шульц родился и практически всю жизнь, за исключением недолгих отлучек в Варшаву, Вену, Львов, Париж, прожил в Дрогобыче, где был застрелен на улице эсэсовцем. При этом, собственно говоря, каких-либо узнаваемых признаков окружающего его украинского/галицкого мира - характерного ландщафта, примет гуцульского быта, одежды, звучания языка и т. п. - в его новеллистиче- 
ских циклах «Коричные лавки» и «Санатория под клепсидрой» нет. Такие признаки угадываются, домысливаются, не более того. Однако это совсем другой случай, нежели такое же отсутствие в польском «мифе Львова». В последнем важная, по сути решающая, роль принадлежала политикопатриотическому фактору, здесь слово «миф» имеет условный характер, это не определение, а литературная метафора. Шульцевский Дрогобыч мифологичен в подлинном, строго терминологическом смысле (см.: [2г]). Украинские черты этого мира не представлены в обеих книгах не потому или не только потому, что повествователь не выходит за пределы города, в сельскую местность, где проживает украинское население, а прежде всего потому, что национальный момент не имел существенного значения для шульцевского «мифа Дрогобыча». Это касается как украинского компонента, так, кстати, и еврейского, главного в мифе Шульца. Отраженные писателем реальные детали местечкового и семейного быта предстают не столько в этнографическом ракурсе, сколько в мифологическом, взаимоотношения дрогобычского купца Якуба с сыном коррелируют с ветхозаветным сюжетом об Иакове и Иосифе.

Тем, чем для Бруно Шульца был Дрогобыч, для Шмуэля Йосефа Агнона (настоящая фамилия - Чачкес, 1887-1970) был город Бучач в Королевстве Галиции и Лодомерии, коронной земле Габсбургской империи (ныне Тернопольской области Украины), где будущий Нобелевский лауреат родился в традиционной и состоятельной еврейской семье торговца, посещал хедер, кроме того, отдельно изучал Тору, Талмуд, иврит под руководством отца и местного раввина.

Агнон с детских лет владел немецким, польским и украинским языками, но писать начал на идише, первые публикации - в журнале "Наmicpeh" («Смотровая башня») и еженедельнике “Jidiszer Weker” («Еврейский будитель»), в газетах Бучача, Коломыи, затем Львова. В г909 г. в Палестине, куда он переехал незадолго до этого, молодой литератор публикует повесть «Покинутые жены» («Соломенные вдовы»), название которой ( עגונות «Агунот») подсказало ему литературный псевдоним («Агнон» в переводе с иврита означает «брошенный»), ставший впоследствии официальной фамилией. На иврите Агнон пишет, живя с I9I2 г. в Берлине, и тем более в последующие годы, окончательно обосновавшись в Палестине, позднее став израильским писателем. 
Еврейская проблематика, безусловно, доминирует в творчестве Агнона, однако она включена в исторический и современный контекст, в исполненную драматизма европейскую панораму XX в., в этнокультурную и конфессиональную реальность Галичины.

В отличие от Бруно Шульца, у Агнона украинское начало проявляется в реальных формах - это персонажи, географические названия, ссылки на исторические имена или события. Как правило, они подаются в позитивном ключе, с доброжелательной интонацией. Так, в одном из ранних рассказов, «Клинок Добуша», используются украинские фольклорные предания об Олексе Довбуше, предводителе карпатских опришков, они переплетены с рассказами о современнике Довбуша, основателе хасидизма Баал-Шев-Тове (Беште), с легендой о побратимстве этих персонажей украинской и еврейской историй. Широк набор галицких топосов: Львов, Станислав, Коломыя, целая цепочка названий местечек и сел - Язловец, Лешкович, Борщев, река Стрыпа... И конечно, главное - Бучач.

В родной Бучач (у Агнона - Шибуш) писатель возвращался постоянно - и физически, в конце г920-х гг., и в художественном воображении.

Для повествователя в романе «Путник, зашедший переночевать» (в английском переводе «Ночной гость») Бучач - город прежде всего еврейский, писатель, однако, смотрит шире. В речи на церемонии вручения Нобелевской премии за этот роман (вкупе со «Свадебным балдахином») Агнон подчеркнул, что в родном городе испытал влияние со стороны всех людей - как евреев, так и не евреев.

Этим мироощущением Агнон обязан многонациональному и поликультурному Бучачу, побывавшему за свою историю галицко-волынским, турецким, польским, австрийским, еврейским, но в конечном счете сохранившему свою изначальную, русско-украинскую природу.

\section{Центральный и восточный регионы}

При переходе к этому разделу отмечаются существенные изменения в природе и функционировании украинско-еврейского пограничья; таких изменений назовем два.

Во-первых, это типологическая трансформация: от непосредственно «пограничного пограничья», так или иначе связанного с фактором границы как геополитического понятия, - к пограничью как понятию «внутренне- 
му», в известном смысле «виртуальному», воображаемому. Такое пограничье относится к социальной антропологии и культурологии, к идеологии и поэтике, к сфере внутрикультурных коммуникаций и взаимовлияний, традиций, сближений и отталкиваний. Имеется в виду также «хвост» стереотипных представлений и законсервированных предрассудков фантомного типа, пришедших из-за границ, которые, отмечает Сабина фон Левис, «уже не существуют политически и легально, однако проявляются ныне в различных формах и измерениях социальных движений и практик...» [26, c. 99]. Такое «фантомное» украинско- и русско-еврейское литературное пограничье сложилось в центральном и восточном регионах Украины в ХХ в., в условиях развала Российской, потом советской империй, ломки границ, бифуркаций и метаморфоз, связанных с переменами как в общественном статусе еврейской культуры, так и с переменами внутри ее самой.

Во-вторых, изменился вектор развития пограничных этнокультурных процессов. Как отмечалось, украинско-еврейскому пограничью Галичины и Волыни была присуща европейская ориентация, прежде всего на Австро-Венгрию и Польшу. У писателей-евреев центрального и восточного пограничных регионов, т. е. территории Российской империи и Советского Союза (УССР), другие ориентиры - русский и украинский. Те, кто родился и вырос в городской среде, прежде всего в значительно русифицированных Одессе, Харькове, Николаеве, частично в Киеве, кто учился в гимназиях, реальных училищах, служил в русской армии, участвовал в Первой мировой или гражданской войнах, - те обычно оставляли семейный и бытовой идиш и в своих литературных опытах переходили на русский. Многие из их числа заняли заметное место - как русские писатели - в советской литературе (И. Бабель, Э. Багрицкий, И. Эренбург, М. Светлов, М. Кольцов, И. Ильф). Следующие поколения формировались в г93о-е гг., в период Второй мировой войны уже целиком на русскоязычной основе: С. Кирсанов, В. Гроссман, В. Инбер, С. Гудзенко, П. Коган, А. Рыбаков, А. Галич, Э. Казакевич (последний, автор русскоязычной прозы, в поэзии сохранил материнский язык - идиш), позднее и в недавнее время - Н. Коржавин, Юнна Мориц, Илана Вайсман, Маргарита и Алла Хемлин, Ирина Левитес, Дина Калиновская.

Писательские судьбы евреев - уроженцев местечек и сельской местности - развивались в двух версиях. Первая - это творчество на идише и/ 
или иврите, преимущественное, точнее, абсолютно превалирующее, внимание к еврейской тематике, характерам, традициям, быту в сочетании с некоторым количеством украинских элементов (топосы, имена и образы людей, сюжетные ситуации, языковые вкрапления).

Вторая версия: выбор в качестве языка творчества украинского языка, как правило, знакомого с детства, по обстоятельствам биографии, с выходом в более широкое, чем еврейское, тематическое пространство, но с сохранением более или менее значительной доли еврейского компонента в том, что касается проблематики, системы характеров, стиля, интонации.

На первом направлении внимание привлекает фигура ШоломАлейхема (Ш. Рабинович, г859-г9г6). Как и у Агнона, у Шолом-Алейхема украинский элемент маргинален, однако, опять же как у Агнона, жизненно достоверен и, пожалуй, в большей степени семантически значим. В текстовую ткань время от времени вплетаются детали, штрихи, маркирующие присутствие в изображаемом мире украинских реалий. Это топонимический ряд, прежде всего Киев, у Шолом-Алейхема он выступает под условным именем Егупец, т. е. Египет, страна изгнания (намек на черту оседлости, ограничивающей право евреев на проживание), и пригородная сельская местность, в конце XIX в. обретавшая черты дачного поселения, Боярка, или, у Тевье (повествователя в цикле рассказов «Тевье-молочник), Бойберик; также Львов и Броды в романе «Мальчик Мотл». Это имена персонажей: Иван Поперило, Федька Галаган, пастух Трохим. Это лингвоэтнические маркеры (тот же «Трохим»), органично вкрапленные в речь Тевье украинские поговорки («Не було у Микиты грошив и не буде!» [33, с. 57], «И Гапка - люди, и Юхим - человек!» [33, с. 92]). Это, наконец, сцена прихода к Тевье во двор толпы представителей сельской «громады». Староста Иван Поперило объясняет цель визита: «Дело, видишь ли, вот какое. Мы, правду сказать, против тебя, Тевль, ничего не имеем. Ты хоть и жид, но человек неплохой <... . Мы тебе хоть стекла повышибаем. Уж это мы непременно должны сделать, а то <...> не ровен час проедет кто-нибудь мимо, пусть видит, что тебя побили, не то нас и оштрафовать могут...» [33, с. 20I].

Если взглянуть на данный эпизод (и в целом на проблему места и семантической функции украинского компонента в еврейском контексте сочинений Шолом-Алейхема) в ракурсе троичной парадигмы «Чужое-ИноеСвое», напрашивается вывод о ключевой роли в ней фактора инаковости: 
участники конфликта с обеих сторон в сущности не «чужие» по отношению друг к другу, хотя и не «свои», они - «иные». Для характеристики этого этнокультурного явления уместными представляются такие этико-психологические понятия, как понимание, приятие, признание, толерантность, которые, правда, нередко подвергаются деформациям под воздействием внешних сил. В целом есть основания говорить об элементах близости этнокультурных позиций Шолом-Алейхема, Агнона и М.-М. Сфорима (с оговоркой о существенно более высокой значимости этнотолерантного момента у автора «Тевье-молочника») и одновременно об их отличии от, скажем, Х.Н. Бялика (I873-1934) или Дер Нистера (П. Каганович, І884-1950).

Критерий инаковости применим и в более широком плане, а именно - для определения места, которое пишущие на идише писатели и их творчество занимали в новейшем украинском культурном контексте. В июле I9I7 г. в Генеральном секретариате (его возглавил В. Винниченко) - исполнительном органе Центральной Рады - с целью активизации политической и культурной жизни еврейского сообщества было создано Министрество (Генеральный секретариат) еврейских дел. Его возглавил Моше Зильберфарб (псевдоним - М. Базин, I876-I934), писавший на идише, русском и немецком языках. В благоприятных условиях развивалась еврейская культура в советской Украине в первые полтора десятилетия после октябрьского переворота, некоторые еврейские писатели-идишисты вернулись из эмиграции, их привлекали как общий дух революционных перемен, так и обозначившийся в стране рост сети еврейских газет и журналов, издательств, учебных заведений, научных центров, что «вселяло надежды на стимулирование советским правительством развития еврейской культуры, в частности и литературы на идише» [7]. «Роман идишистских писателей с коммунизмом» (это название книги профессора Сиракузского университета Г.Дж. Эйстраха (см.: [25]) закончился трагически, волна репрессий рубежа 1940-1950-х гг. поглотила многих еврейских писателей, но в 1920-х - в первой половине г930-х литература на идише развивалась бурно. Харьков, тогдашняя столица Украины, был одним из центров этого процесса, с ним связаны судьбы и творчество виднейших еврейских писателей - Давида Гофштейна (г889-І952), Льва (Лейбы) Квитко (I890-I952) и Переца Маркиша (I895-I952).

Своеобразная фигура в литературном Харькове той эпохи - Бен Яков (Калмен Зингман). Его незавершенный роман-утопия «Эдения: в 
городе будущего», написанный на идише и опубликованный в Харькове в I9I8 г., лишь сравнительно недавно увидел свет в Израиле и в переводе на украинский [27]. В романе Зингмана в радужных красках (название отсылает к библейскому Эдему) изображается жизнь украинского еврейства в недалеком будущем - в середине г940-х гг. на фоне высочайшего уровня технического и культурного развития Харькова, где в рамках еврейской идишистской (диаспорной - в противовес ивритско-палестинской утопии, созданной Теодором Герцлем в романе «Старая новая земля» [“Altneuland”, I902]) соцалистической утопии воплощена идея гармонии украинского и еврейского начал, экономического и этнокультурного равноправия. Два «иных» сливаются у Зингмана в единое «свое».

с) Украинские писатели еврейского происхождения социопсихологический вариант этнокультурного пограничья

Два момента представляются определяющими для понимания природы и сущности данного явления. Во-первых, это характерная для конца XIX - первых десятилетий XX в. интенсификация таких общецивилизационных модернизационных тенденций, как урбанизация, развитие промышленности и образования, стимулирующих ассимиляционные тенденции, выход представителей еврейского населения, прежде всего молодых поколений, из замкнутого местечкового мира, интеграция евреев в общекультурные процессы, в производственную, политическую и общественную жизнь. Во-вторых, специфика социально-исторических условий и обстоятельств, в которых эти процессы проходили в центральном и восточном регионах Украины на разных этапах исторического развития: колониальный статус украинской культуры в Российской империи, затем его поэтапная реанимация в «социалистических» формах; активизация движения украинского национального духовно-культурного возрождения во второй половине XIX в., кризис и развал имперской системы, революционные пертурбации и модерные дискурсы постоктябрьской эпохи.

Одно из проявлений этих процессов в литературной практике - факты выбора писателями еврейского происхождения, уроженцами Украины, украинского языка в качестве языка творчества и тем самым включения их в общеукраинский литературный процесс. Подобного рода примеры не уникальны, они известны из истории ряда литератур Центральной и Вос- 
точной Европы, однако имеют место существенно важные различия, связанные с социальными предпосылками и психологическими мотивациями подобного выбора. Когда уроженец еврейского галицкого местечка (скажем, К.Э. Францоз и Й. Рот) или пражского еврейского гетто (Ф. Кафка) делал языком своего творчества немецкий язык, а выходец из патриархальной еврейской дрогобычской семьи Б. Шульц - польский, это было объективно, независимо от конкретных обстоятельств и личных устремлений, фактом интеграции представителя этнического меньшинства в господствующую культуру, имперскую, государственную, в культуру титульной нации. То же относится и к выбору русского языка представителями некоторых, преимущественно состоятельных, еврейских семейств Надднепрянской Украины (И. Бабель, И. Эренбург).

Иное дело - выбор в пользу притесняемых языка и культуры, каковыми являлись (или были совсем недавно, если говорить о первом послеоктябрьском десятилетии) украинские язык и культура. Принципиальное значение в подходе к проблеме приобретает понятие антиимперского выбора, оно выступает в качестве ключевого в фундаментальной монографии профессора Северо-Западного университета США (Иллинойс) Йоханена Петровского-Штерна «Антиимперский выбор. Становление украинско-еврейской идентичности». Как говорит автор во «Вступлении», книга посвящена писателям-евреям, которые «интегрировались в украинское общество» при том, что воспитывались они в идишистской среде и нередко обучались в русскоязычных учебных заведениях; для них «Украина была желанной средой, украинская культура - источником вдохновения, а украинская тематика - частью их творческих поисков» [І8, с. 23].

Подобные тенденции «неимперской интеграции» имели место в национальных культурах ряда восточноевропейских народов в определенные периоды их истории, например, в Польше, разделенной между двумя империями (Ю. Клячко, В. Ордон [Шанцер], Я. Корчак), в Чехии во второй половине XIX - на рубеже XIX-XX вв., до обретения ею самостоятельности (3. Каппер, Ф. Гельнер, О. Фишер, К. Полачек); в белорусской литературе примером ассимиллированного писателя-еврея был Змитрок Бядуля (Шмуэль-Нохим Плавник). В украинском литературном дискурсе критерием выявления поведенческих моделей украинских писателей-евреев, их антиимперских рефлексий становится причастность к движению 
украинского национального возрождения на разных этапах его исторического развития.

Что касается сферы психологии творчества, собственно литературной реализации выбора писателями еврейского происхождения украинского языка, то конкретные формы такой реализации были, разумеется, разными. Объединяющим моментом следует считать общий вектор, направленный на сближение «своего» с «иным», на трансформацию - или, скажем осторожнее, на попытки такой трансформации - «иного» в «свое», на поиск синтеза того и другого.

Вот несколько бегло очерченных, но характерных для рассматриваемой в данной статье эпохи (последняя четверть XIX - первая половина $\mathrm{XX} \mathrm{в.)} \mathrm{историко-литературных} \mathrm{силуэтов.}$

Кесарь Александрович Белиловский (г859-г938 (34?), литературные псевдонимы - Цезар Білило, Цезарко, Іван Кадило) (см.: [гз]). Латинское имя Кесарь (Кесарий), мальчика из еврейской семьи (а другое, традиционное, еврейское, так называемый руф новэм, по Библии или Талмуду, нигде не упоминается), наталкивает на предположение, что эта семья не была патриархальной. Общались ли в семье на идише? Скорее всего - да. Но наверняка бытовал и украинский, без которого глава семьи, фельдшер сельской больницы с. Стополивка, Полтавской губернии (ныне с. Вознесенское Черкасской области), никак не мог бы обойтись. Хедер, с его ритуальным ивритом, мальчик не посещал, зато был отправлен в Полтавскую гимназию, разумеется, русскоязычную, и именно там - парадокс - написал свои первые стихи на украинском языке, в подражание Т. Шевченко. С творчеством Шевченко связан один из первых переводческих опытов Белиловского: обучаясь в Лейпцигском университете, он, по совету Ф. Боденштадта, знатока и переводчика русской и украинской литературы, публикует в газете "Leipziger Theater- und Intelligenzblatt" (г2.03.І876) свой перевод стихотворения Т. Шевченко «Думка. - Нащо мені чорні брови». В Лейпциге, до этого в Дерпте, затем в Венском и Йенском университетах Белиловский изучал медицину, которая стала его титульной профессией. Судьба сложилась так, что бо́льшую часть жизни он провел вдали от родных мест, жил в Петербурге, немного в Москве, в качестве врача служил в разных концах империи - Петропавловск (Казахстан), Петрозаводск, Митава, Феодосия, Симферополь (где умер и похоронен), в Персии, при советском консуль- 
стве, но душою всегда оставался с Украиной, и главной связующей нитью была его общественная и литературная деятельность на ниве украинского слова. Еще в молодости, будучи студентом Венского университета, Белиловский сблизился с украинской студенческой организацией народнического типа «Січ» («Сечь»). Позднее, в г89о-е гг., живя в Петербурге, Белиловский выступил одним из инициаторов и организаторов чествования Шевченко, статьи с рассказом об этих мероприятиях опубликовал во львовском журнале «Зоря». Там же было опубликовано его стихотворение «Роковини Тараса» («Годовщина Тараса»), прочитанное в Петербурге на шевченковском вечере. Белиловский переписывался с И. Франко, участвовал в издаваемом Франко и И. Белеем журнале «Світ» («Мир»)

Некоторые поэтические произведения К. Белиловского - «У батьківському краї» («В отцовском краю»), «Житейський досвід» («Житейский опыт»), «Червоний шлюб» («Красный брак»), «Сум» («Печаль»), «Тиха ніч» («Тихая ночь»), «Ользі» («Ольге»), сатирическое стихотворение «Клим Ганеба» - пользовались популярностью, а стихотворение «В чарах кохання» («В чарах любви»»), выдержанное в традиционном стиле лирического монолога влюбленной девушки, было положено на музыку Н. Леонтовичем. К. Белиловский одним из первых в украинской поэзии (вслед за А. Крымским) обратился к восточной тематике: лирический цикл «Персіянські мотиви» («Персидские мотивы»), поэма «Цар Джеган, або Мармуровий сон» («Царь Джеган, или Мраморный сон»), поэтические реминисценции на мотивы казахского фольклора.

Грищъко Кернеренко (Гирш бен Борух, Григорий Борисович Кернер, I863-I92I) - младший современник К. Белиловского. Событийные линии их биографий практически нигде не пересекаются, учебу обоих в Германии не стоит в этом смысле принимать во внимание - время учебы, города и учебные заведения разные. Был один пункт такого пересечения (впрочем, лишь возможного) - харьковский кружок В. Александрова (І829-I894), военного врача, писателя, фольклориста, известного собирателя украинской старины. В издаваемом Александровым альманахе «Складка», выход которого был положительно отмечен И. Франко, печатался Белиловский, он же после смерти Александрова опубликовал воспоминания о нем и при участии Б. Гринченко и М. Кропивницкого издал в Харькове и Петербурге два выпуска альманаха в память о его основателе. Правда, сведений о зна- 
комстве или тем более сотрудничестве Кернеренко с Белиловским, хотя бы заочном, нет.

Есть все же один пункт «пересечения» обоих писателей, это черты типологического сходства их литературных биографий. Оба своим происхождением и семейным воспитанием были связаны (при всем различии конкретных обстоятельств) с еврейской средой, со смешанным идишистским, русско- и украинскоязычным окружением, оба в зрелые годы были состоявшимися и успешными как профессионалы. И оба в своем литературном творчестве сделали решительный выбор в пользу украинского языка и национальной литературной традиции - фольклорной и шевченковской.

Гирш бен Борух Кернер родился и вырос в слободе Гуляйполе (ныне это город в Запорожской области), в семье богатого предпринимателя, основателя солидной, широкого - от винокурения до производства сельскохозяйственных машин - профиля компании «Б.С. Кернер и сыновья». На протяжении всей жизни, до самой смерти, случившейся в І92I г. при так и не выясненных обстоятельствах (вспомним, что́ представляло собою Гуляйполе в разгар гражданской войны), он участвовал в бизнесе в качестве одного из «сыновей». А параллельно существовал Грыцько Кернеренко, еврейский украинофил, читатель и подписчик украинских изданий, автор пяти сборников стихов и прозы на украинском языке, пьесы из украинской народной жизни. Он был практически неизвестен гуляйпольскому еврейскому предпринимательскому сообществу и русифицированной местной украинской интеллигенции, но его стихи публиковались в антологиях, на страницах украинских газет, журналов и альманахов, его творчество положительно оценивали И. Франко, В. Александров, Христя Алчевская, Н. Шаповал.

Авторы редакционной статьи в № I за 2005 г. журнала “Ab Imperio”, где, в частности, анонсируется публикация статьи Й. Петровского-Штерна о Григории Кернере (Грыцько Кернеренко), суть феномена «интеграции [еврея] в формирующийся украинский национальный проект» усматривают в том, что поэт пишет стихи на украинском языке, «облекая свою еврейскую идентичность в термины украинского национального возрождения» [I7, с. 2I]. Думается, эта формулировка упрощает сложнейшую социокультурную и психологическую проблему. Речь идет не о «переодевании» идентичности, а о линейке понятий, касающихся новых черт идентичности, ее nрироды, - «трансформация идентичности», «гибридная идентичность», 
«пограничье идентичностей», «синтез идентичностей», в случае Кернеренко (по Петровскому-Штерну) - «украинско-еврейская идентичность».

Грыцько Кернеренко, выбрав украинский язык, не отказался от своего еврейства. В его итоговом сборнике «Ме́нти натхнення» («Моменты вдохновения»), в переводах поэтических произведений писавшего на русском и на идише Шимона (Семена) Фруга (г860-I9I6) представлена еврейская тематика (ветхозаветные реминисценции, религиозная метафорика, отголоски сионистских мотивов, эмоциональные реакции на погромы).

При этом в качестве доминантной в творчестве Кернеренко выступает тема Украины - «святой Украины», «батьківщини» («родины»), «неньки» («мамы»). Его Украина - это поэтическая легенда, в которой прекрасная утопия слита с драматизмом исторической судьбы, идеализированный образ, отмеченный мощным влиянием (и, призна́ем, подражательностью) шевченковской традиции, личности великого Кобзаря. Драматическими нотами проникнуто самоощущение поэта, его попытки осознания своей «гибридной» идентичности.

Раиса Троянкер (1909-1945). Литературный Харьков г920-х гг. представлял собою пестрое сообщество неординарных, подчас экстравагантных личностей, но даже на этом фоне приехавшая в столицу из провинции юная поэтесса выделялась своим темпераментом, неуемной энергией, неординарными - нередко на грани эпатажа - поступками. И еще какой-то колдовской женской привлекательностью, манящими эротическими токами, от которых перехватывало дыхание у представителей мужского большинства участников богемных вечеров в Доме писателей им. В. Блакитного (см.: [20]).

Этими токами была пронизана и ее поэзия, что, согласно расхожим представлениям и советским литературоведческим стереотипам, противоречило целомудренной национальной традиции, хотя непредвзятое прочтение некоторых фольклорных и классических текстов украинской литературы, не говоря уже о близких Раисе авангардистах г920-х гг., подсказывает иные оценки и выводы (см.: [23; 24]). Но сравниться с ней ни по месту эротики в творчестве, ни по степени ее суггестивности никто из них не может.

А ведь Раиса родилась в патриархальной еврейской семье уманского шамеса, синагогального служителя, где царили традиционный уклад, ортодоксальная религиозная атмосфера, строгие правила талмудической этики. 
Девочка взбунтовалась рано, импульсы к бунту были разные - витающий в воздухе дух революционных перемен, ломки всего и вся, природная пылкость натуры, раннее пробуждение чувственности, женского эго («Рай-Я» так она расшифровывала смысл своего имени); первым всплеском этого бунта был бурный роман с заезжим цирковым укротителем, выступления на арене с тигром, в пасть которого она клала свою буйную голову...

Тогда же и там же, в Умани, зародилась любовь к поэзии и тяга к собственному творчеству. Сначала это была увлеченность русскими поэтами Серебряного века, особенно А. Ахматовой и Н. Гумилевым, сохранившаяся, впрочем, на долгие годы, затем влюбленность во Владимира Сосюру, что, похоже, и положило начало ее собственному поэтическому творчеству, причем на украинском языке. Украинский «выплыл» из сформированной местечковой языковой ситуацией памяти, в которой смешались семейный идиш, уличное украиноязычье и корявый русский укротителя Джордани (итальянца?). Раиса публикует в уманской газете «Робітничо-селянська правда» стихотворение на украинском языке, вступает в местное отделение Союза крестьянских писателей «Плуг». Вскоре она выходит замуж за члена этой группы, украинского критика Онуфрия Тургана, что приводит к конфликту с родителями, прежде всего с отцом. Об этом она позднее напишет:

\begin{abstract}
Меня отец прогнал и проклял, потому что у меня дитя от «гоя». Он сказал, чтоб упала земля под нами, Оленка7 ${ }^{7}$ с тобою ${ }^{8}$.
\end{abstract}

(Подстрочный перевод мой. - Ю.Б.)

В середине І920-х молодая литературная семья переезжает в Харьков, который был тогда не только административной, но и интеллектуальной и культурной столицей Украины, духовным и организационным центром национального культурного возрождения (позднее названного «расстрелянным»), одной из примечательных черт которого было, кстати,

7 Оленка - это будущая московская журналистка Елена Турган, ее дочь, внучка Р. Троянкер, Александра Турган, актриса, в г980-е гг. служила в театре «Современник».

8 Троянкер Р. Повінь. [Поезіі]. [Х.]: Плужанин, [1928]. С. 23-24. 
активное участие еврейских писателей, как идишистских, так и украиноязычных. Раиса оказалась в самой гуще тогдашней украинской литературной жизни, это были лучшие годы в ее поэтической биографии, а может быть, и в жизненной судьбе. В Харькове выходит два сборника ее стихов, «Повінь» («Половодье») и «Горизонт», в которых окрашенные ностальгией воспоминания о «штетле» переплетаются с утопическими мотивами национально-революционного толка и, добавим, корректируются этими мотивами. Этот симбиоз в целом и каждый из его компонентов в отдельности обволакиваются густой и вязкой эротической субстанцией.

Очередной роман и брак с русским поэтом Ильей Садофьевым, переезд в I93І г. в Ленинград поставили точку в деятельности Р. Троянкер как украинской поэтессы. Стихи, уже по-русски, она некоторое время писала, даже выпустила один русскоязычный сборник. После развода с Садофьевым уехала в Мурманск, где была уважаемым и популярным журналистом «Полярной правды», в годы войны - фронтовым корреспондентом. Умерла от тяжелой болезни в г945 г.

Уровень поэтического мастерства Раисы Троянкер невысок, украинский язык далек от совершенства. Ее поэтическое наследие, личная и литературная судьбы представляют интерес как один из случаев еврейскоукраинского лингво- и этнокультурного пограничья в контексте украинского культурного возрождения 20-х гг. XX в. В более широком, историко-культурологическом плане это социопсихологический феномен, объект нациологических штудий, пример изменчивой, «текучей» идентичности.

Иван Юлианович (Израиль бен Егуда) Кулик (1897-1937) начинал свою литературную деятельность в той же, что и Раиса Троянкер, Умани (родился недалеко, в местечке Шпола Киевской губернии), но это единственный момент сходства между ними.

Прежде всего, совершенно разными были языковые «маршруты» их творчества. Р. Троянкер начинала с украинского. Первое стихотворение Кулика было опубликовано в русской уманской газете «Провинциальный голос». Кулик закончил в Умани русское четырехклассное училище, поступил в Одесскую художественную школу. Это, судя по всему, было продуманной родителями сугубо прагматической стратегией, направленной на то, чтобы открыть перед ним более широкие жизненные горизонты. К тому же, по свидетельству современников, в семье, хотя отец был меламедом, учителем 
хедера, общались по-русски. Вместе с тем есть основания предположить, что Кулик с детства знал идиш и литературу на идише: в I9I6 г., в Америке, куда семья иммигрировала накануне Первой мировой войны, Кулик опубликовал в нью-йоркской русской социал-демократической газете «Новый мир» заметки о Шолом-Алейхеме, Ицхоке-Лейбуше Переце и Шимоне Фруге, а в І930 г., уже в Советском Союзе, в каменец-подольской украинской газете «Червоний кордон» об Иосифе Бовшовере (1873-1915), назвав его «первопроходцем еврейской пролетарской поэзии». К литературному творчеству на украинском языке (первый сборник стихов Кулика на украинском языке «Мої коломийки» [«Мои коломыйки»] увидел свет в І92г г. в Харькове) пришел от семейного и школьного русского и суржика шполянского «штетла», от первых уроков украинского, полученных в мальчишеской среде городского уманского парка «Софиевка». Его путь в украинскую литературу был «окружным», зато, в отличие от того, как сложилось у Р. Троянкер, Кулик, выбрав в качестве языка своего творчества украинский, оставался в его гравитационном поле до конца.

Разными были и мотивации. У Троянкер интимный, субъективный фактор - роман с украинским поэтом - предопределил этот выбор и затем вхождение в украинскую литературную среду, как, впрочем, впоследствии и выход из нее. Для Кулика решающую роль сыграли его марксистские (в той мере, в какой он их считал таковыми) взгляды и вытекающая из них антиколониальная, антиимперская ориентация. Его увлеченность идеей украинского национального возрождения и активная деятельность по ее реализации (опять-таки - в его, члена большевистской партии, понимании и трактовке) были причудливым образом связаны с коммунистической утопией, с иллюзорными представлениями о международной пролетарской солидарности и роли Украины/УССР в мировой революции.

Соответственно, разными были биографии обоих писателей. Если Троянкер - поэт, прежде всего и только поэт, то для Кулика писательство было частью его большой политической и общественно-литературной карьеры (или, в известном смысле, приложением к ней, или своего рода «отдушиной»). Вернувшись в I9I7 г. из Америки, Кулик погрузился в политический водоворот, на протяжении I920-х - первой половины I930-х гг. 
он занимал важные посты в партийной, военной, государственной, дипломатической (советский консул в Канаде), литературной сферах, был одной из ключевых фигур в литературно-политической жизни УССР, возглавлял Союз советских писателей Украины, ряд издательств, редакций литературных газет и журналов. В г937 г. репрессирован и расстрелян.

Достаточно обширное украиноязычное литературное наследие И. Кулика (сборники стихов, роман, повесть, переводы, главным образом с английского) отмечено печатью эпохи, революционной лозунговостью, политических и идеологических компромиссов. Эстетическая ценность сочинений Р. Ролинато, Василя Роленко, Ральфа К. Ролинато (литературные псевдонимы Ивана Кулика) невысока, это факт истории украинской литературы советского периода, имеющий прежде всего этнокультурное и социопсихологическое значение.

Леонид Первомайский (Илья Шлемович Гуревич) (1908-І973) родился в полиэтническом и полилингвальном городке/полуместечке/полуселе Константинограде Полтавской губернии (б. Белевская крепость, ныне Красноград Харьковской области). Семья переплетчика Шлемы Гуревича не была патриархальной, бытовой русский язык лишь изредка перебивался идишизмами, за стеной, у соседей-квартиросъемщиков, звучала украинская речь вперемешку с русской, как и на улицах, на базарной площади, в среде рабочих пивоваренного, сахарного и черепичного заводов, а в хедере, куда отдали Илюшу, наряду с Торой, в обязательном порядке преподавались русский язык и литература. Впрочем, русские, как и украинские, книги мальчик читал взахлеб, помогая отцу в его переплетном деле, кроме того, те и другие легко можно было найти в книжном киоске Йоськи Рудого. Но главная - для Первомайского - партия в этом многоголосье принадлежала матери, еще не старой, но рано поседевшей еврейке, ее украинскому языку и украинской песне. В стихотворении «На українській золотій землі» («На украинской золотой земле») читаем:

...В моих песнях звучат ее песни; из ее уст я впервые услышал слово, которому потом дал крылья... (Подстрочный перевод мой. - Ю.Б.) 
Подчеркнутая акцентуация поэтом метафорического образа-парадокса «еврейская мать как носитель украинского языка» - знак осознания им высокой степени органичности своего литературного украиноязычья. Украинский язык оказался средством максимально полного и адекватного выявления Первомайским своей еврейско-украинской идентичности, реализации творческого потенциала, стал одним из факторов, предопределивших значимость того места, которое его еврейско-украинский дискурс занимает в новейшей украинской литературе.

Еврейско-украинская идентичность Первомайского не была, в отличие от разобранных выше случаев, ни «гибридной», ни двойной, она была двуединой, цельной. Не была она также явлением статичным, свободным от влияний как «духа времени», внешних факторов, так и от связанных с этими факторами внутренних противоречий и трансформаций. Если подойти к еврейскому дискурсу в творчестве Первомайского как к некой структурно-семантической целостности, в нем следует различать две составляющих: еврейскую тему - исходную, относительно постоянную единицу, и рему - ее, темы, интерпретацию с учетом особенностей того или иного семантического и ситуативного поля, меняющихся исторических контекстов. В еврейском дискурсе Первомайского и в еврейско-украинском сегменте этого дискурса могут быть вычленены три таких исторических контекста, отражающих степень и формы включенности писателя в процесс украинского национального возрождения на его разных исторических этапах.

Это -

а) г920-е - первая половина г930-х гг.:

- революционно-комсомольский период в жизни страны и в биографии писателя; выбор знакового псевдонима «Первомайский»;

- литературный Харьков эпохи украинского культурного возрождения, творческая близость с Иваном Куликом;

- активная разработка еврейской темы в русле идей социального обновления и национального возрождения; мотивы разрыва с местечковым прошлым, интеграции еврейства в новую жизнь, утопические проекты создания еврейских колхозов (пьеса «Местечко Ладеню», повесть «Земля обетованная») как попытки переинтерпретации библейского образа;

b) вторая половина 1930-х - середина г940-х гг.: 
- в условиях обострения репрессий, в том числе связанных с национальным вопросом, ужесточения идеологического контроля еврейский дискурс уходит с поверхности творчества Первомайского;

- этот дискурс активизируется в годы войны, обретая острую антинацистскую направленность, ключевыми становятся темы Холокоста, Бабьего Яра;

- мотивы интернационального братства, переплетения украинских и еврейских судеб в драматических обстоятельствах общенародной трагедии;

c) 1950-е - первая половина г970-х гг.:

- начавшаяся в конце г940-х и продолжавшаяся в последующие десятилетие травля за «безродный космополитизм» вынуждала Первомайского отстаивать свою еврейско-украинскую идентичность, право, оставаясь евреем, быть украинским писателем (именно тогда, в 1949 г., было написано стихотворение «На украинской золотой земле», строки из которого приводились выше);

- по своей глубинной сути это была форма духовного сопротивления, подспудного участия в назревающем новом подъеме украинского национального возрождения;

- одновременно в творчестве писателя шел процесс углубления собственно еврейского дискурса, раскрытия его общечеловеческого и общекультурного, гуманистического содержания, этим пафосом проникнута переводческая деятельность Первомайского, в частности, перевод на украинский поэзии Генриха Гейне - в известном смысле его немецко-еврейского alter ego;

- очевидна сопоставимость этой тенденции с присущим тогдашнему украинскому диссидентскому движению - «шестидесятничеству» отказом от провинциализма, «малороссийской» ограниченности, с его ориентацией на гуманистические ценности мировой культуры.

$* * *$

Творчество Леонида Первомайского, как и ряда его современников (Н. Рыбак, С. Голованивский, А. Кацнельсон, М. Талалаевский, Л. Юхвид, Е. Мартич, С. Журахович, Н. Тихий), характеризует советский этап процесса интеграции еврейских писателей в украинскую литературу и, по-ви- 
димому, одновременно завершает его; если это так (время покажет), то завершает «на высокой ноте». Преемником Первомайского в утверждении и развитии феномена еврейско-украинской идентичности стал Моисей Фишбейн (1946-2020), в чьей поэзии уникальным образом сочетаются укорененность в мифорелигиозной еврейской почве и безграничная вера в творческий потенциал украинского языка, в его сакральную роль и мессианское предназначение как фактора национального возрождения и обновления Украины. Хотя М. Фишбейн начинал еще в советское время, его поэзия и весь творческий облик - это знаковые явления постсоветского этапа истории Украины, украинской литературы, а в более широком, общецивилизационном, контексте - эпохи милленарного пограничья с присущим ей сочетанием (противоречивым, зачастую конфликтным) черт этнонациональной идентичности с глобалистскими тенденциями, новыми векторами интегративного, транснационального и транскультурного коммуницирования (см.: [I]).

Вписывающиеся в этот контекст специфические черты еврейскоукраинской идентичности М. Фишбейна пока в полной мере не проанализированы и не осознаны, хотя его творчество отнюдь не обойдено критикой [4; II; I8], как не прояснены возможные тенденции и пути развития украинско-еврейского литературного пограничья. Эта работа впереди.

Последнее замечание, впрочем, может быть отнесено к этнокультурному пограничью в целом, в многообразном спектре его конкретных проявлений и форм, в диахроническом и синхроническом аспектах. Актуальность и перспективность этого научного направления представляются очевидными.

\section{Список литературы}

\section{Исследования}

I Антонов С., Розанова М. Идентичности в эпоху глобальных миграций. СПб.: Деан, 2010. $272 \mathrm{c}$.

2 Барабаш Ю.Я. Этнокультурное пограничье: Концептуальный, типологический и ситуативный аспекты (Чужое - Иное - Свое) // Studia Litterarum. 20I9. Т. 4, № 3. С. 290-329. DOI: 10.22455/2500-4247-2019-4-3-290-329

3 Барабаш Ю.Я. Этнокультурное пограничье: Концептуальный, типологический и ситуативный аспекты (Чужое - Иное - Свое). Статья вторая: Харьков. Дон- 
басс - этно- и лингвокультурное пограничье // Studia Litterarum. 2020. T. 5, № 2. С. 286-32I. DOI: I0.22455/2500-4247-2020-5-2-286-32I Барабаш Ю.Я. Украинское литературное зарубежье. Лица. Судьбы. Тексты. М.: ИМЛИ РАН, 20I6. 376 с. Бахтин М. Собр. соч.: в 7 т. М.: Русские словари; Издат. дом «ЯСК», 2002. Т. 6. $800 \mathrm{c}$.

Башляр Г. Избранное. Поэтика пространства / пер. с франц. М.: Российская политическая энциклопедия (РОССПЭН), 2004. 376 с.

Гетманский Э. Советская литература на идиш // Заметки по еврейской истории. 20I7. № II-I2 (204). URL: http://z.berkovich-zametki.com/2OI7-nomerII-I2getmansky/ (дата обращения: г2.05.2019).

8 Гольдельман С.I. Жидівська національна автономія на Україні (I9I7-I920 pp.) / Записки Наукового товариства ім. Т.Г. Шевченка. Т. І82. Праці історично-філософічної секції НТШ. Мюнхен; Париж; Єрусалим: Дніпрова хвиля, І963. I44 с. Грабович Г. Єврейська тема в українській літературі XIX та XX сторіччя // Грабович Г. До історіії української літератури. Київ: Основи, І997. С. 238-258. Грицак Я. Пророк у своїй вітчизні. Франко та його спільнота (І856-г886). Київ: Критика, 2006. 632 с.

II Дзюба İ. Віра в покликаність (вступна стаття до книги «Ранній рай» - Київ, 2006) // День. 27.05.2020.

I2 До редакції журналу «Русский вестник». Листопад I858. С.-Петербург // Шевченко Т. Повне зібрання творів: у г2-ти томах. Київ: Наукова думка, 2о03. Т. 6. С. 222-223 (текст), 534-537 (примітки). Заславський І., Захаркін С. Спогади Кесаря Білиловського // Київська старовина. 2000. № I. C. I34-I54.

I4 І̇льницький М. Поєдинок із собою: проблема двійництва в «Поєдинку» I. Франка та «Двійнику» Ф. Достоєвського // Слово і Час. 2006. № 8. С. г8-27. Костенко Н. Традиції українського бароко в творчості Миколи Бажана // Питання літературознавства. Чернівці, І996. Вип. 3 (60). Слов’янські літератури. C. $36-45$.

I6 Лавріненко Ю. Розстріляне Відродження. Антологія І9І7-г933. Поезія-ПрозаДрама-Есей. Париж: Instytut Literacki, I959. 980 с.

I7 От редакции. Языки самоописания империи и нации как исследовательская проблема и политическая дилемма // Ab Imperio. 2005. №I. С. II-22.

I8 Петровський-Штерн Йоханен. Анти-імперський вибір. Постання українсько-єврейської ідентичности / Авторизований переклад з англійської П. Грицака та М. Климчука, за редакцією В. Дивнича. Київ: Критика, 2о18. 432 с.

I9 Селівановський О. Куди прямує Бажан? // Критика. І931. № 4. С. 39-47.

20 Смолич Ю. Рая. 3 «Інтимної сповіді» // Коментар. 2004. № 3. С. I5. 
Сухомлинов О. Етнокультурний дискурс в літературі польсько-українського пограниччя XX століття. Донецьк: ЛАНДОН-XXI, 20I2. 376 c.

Франко İ. До історії українського вертепу XVIII в. // Записки Наукового товариства ім. Шевченка. Львів, 1906. T. LXXII. С. І70-210.

Цимбал Я. Секс і контекст // Критика. 2009. Ч. 5-6. С. 3I-33.

Цимбал Я. «Хай живе прилюдний поцілунок в голу грудь!»: проблеми видання та коментування приватних документів інтимного характеру // Спадщина: Літературне джерелознавство. Текстологія. Київ: Laurus, 20II. Т. 6. С. 65-87.

25 Estraikh, Gennady J. In Harness: Yiddish Writer's Romance with Communism. Syracuse: Syracuse University Press, 2005. $224 \mathrm{p}$.

Löwis, Sabine von. Phantom borders in the political geography of East Central Europe: an introduction // Erdkunde. Archive for Scientific Geography. 2015. Vol. 69. Issue 2. P. 99-106.

\section{Источники}

27 Бен Яков (Калмен Зінгман). Еденія: У місті майбутнього. Харків: Їдиш, I9I8. (Переклад із мови їдиш Тетяни Батанової та Наталії Риндюк) / Judaica Ukrainica. 20I4. № 3. C. 23I-255.

28 Гоголь Н.В. Полн. собр. соч.: в г4 т. М.: Изд-во АН СССР, І937. Т. 2. 763 с.

29 Гранах А. Вот идет человек / пер. К. Тимофеевой. СПб.: ИД Ивана Лимбаха, 2017. $464 \mathrm{c}$.

30 Коцюбинский М. Избранные произведения / пер. с украинского, ред. и вступ. ст. А. Дейча. М.: Гос. изд-во худож. лит., І949. 376 с.

3I Франко I. Мозаїка. Із творів, шо не ввійшли до Зібрання творів у 50 томах. Львів: Каменяр, 200I. 434 с.

32 Шевченко Т. Собр. соч.: в 4 т. М.: Правда, І977. Т. І. 432 с.

33 Шолом-Алейхем. Тевье-молочик. СПб.: Азбука, 2020. 224 с.

\section{References}

I Antonov, S., Rozanova, M. Identichnosti v epokhu global'nykh migratsii [Identities in the Era of Global Migrations]. St. Petersburg, Dean Publ., 20Io. 272 p. (In Russ.)

2 Barabash, Iu.Ia. "Etnokul'turnoe pogranich'e: Kontseptual'nyi, tipologicheskii i situativnyi aspekty (Chuzhoe - Inoe - Svoe)" ["Ethnocultural Frontier: Conceptual, Typological, and Circumstantial Aspects (Alien - Other - One's own)"]. Studia Litterarum, vol. 4, no. 3, 20I9, pp. 290-329. (In Russ.) DOI: I0.22455/2500-42472019-4-3-290-329

3 Barabash, Iu.Ia. “Etnokul'turnoe pogranich'e: Kontseptual'nyi, tipologicheskii i situativnyi aspekty (chuzhoe - inoe - svoe). Stat'ia vtoraia: Khar'kov. Donbass - etnoi lingvokul'turnoe pogranich'e” ["Ethno-cultural Borderline: Conceptual, Typological, 
and Circumstantial Aspects (Alien - Other - One’s own). Second article: Kharkov. Donbass - Ethno-linguistic and Cultural Borderland"]. Studia Litterarum, vol. 5, no. 2 , 202O, pp. 286-32I. (In Russ.) DOI: IO.22455/2500-4247-2020-5-2-286-32I Barabash, Iu.Ia. Ukrainskoe literaturnoe zarubezh'e. Litsa. Sud'by. Teksty [Ukrainian Literary Abroad. Personalities. Fates. Texts]. Moscow, IWL RAS Publ., 20I6. 376 p. (In Russ.)

5 Bakhtin, M. Sobranie sochinenii: $v 7 t$. [Collected Works: in 7 vols.], vol. 6. Moscow, Russkie slovari Publ., Izdatel'skii dom “IaSK” Publ., 2002. 800 p. (In Russ.)

6 Bashliar, G. Izbrannoe. Poetika prostranstva [Selected Works. Poetics of Space], trans. from French. Moscow, Rossiiskaia politicheskaia entsiklopediia (ROSSPEN) Publ., 2004. 376 p. (In Russ.)

Getmanskii, E. “Sovetskaia literatura na idish” ["Soviet Literature in Yiddish”]. Zametki po evreiskoi istorii, no. II-I2 (204), 20I7. Available at: http://z.berkovich-zametki. com/2OI7-nomerıI-I2-getmansky/ (Accessed I2 May 20I9). (In Russ.) Gol'del'man, S.I. Zhydivs'ka nacional'na avtonomija na Ukrai'ni (I9I7-I920 rr.) [Jewish National Autonomy in Ukraine (I9I7-1920)]. Series: Zapysky Naukovogo tovarystva im. T.G. Shevchenka [Proceedings of the Shevchenko Academic Group], vol. I82: Praci istorychno-filosofichnoi' sekcii' NTSh [Proceedings of the SAG Historical and Philosophical Section]. Mjunhen, Paryzh, Jerusalym, Dniprova hvylja Publ., I963. I44 p. (In Ukrainian) Grabovych, G. “Jevrejs'ka tema v ukrai'ns'kij literaturi XIX ta XX storichchja” [“Jewish Theme in Ukrainian Literature of the $\mathrm{I}^{\text {th }}$ and $2 \mathrm{O}^{\text {th }}$ Centuries"]. Grabovych, G. Do istoriii' ukrai'ns'koi' literatury [On the History of Ukrainian Literature]. Kiev, Osnovy Publ., I997, pp. 238-258. (In Ukrainian) Grycak, Ja. Prorok u svoi'j vitchyzni. Franko ta jogo spil'nota (I856-I886) [Prophet in His Own Country. Franco and His Community (I856-I886)]. Kiev, Krytyka Publ., 2006. 632 p. (In Ukrainian) Dzjuba, I. “Vira v poklykanist’ (vstupna stattja do knygy 'Rannij raj’ - Kyi’v, 2006)” ["Belief in Vocation (Introduction to the Book 'Early Paradise' - Kyiv, 2006)"]. Den', 27 May 2020. (In Ukrainian) "Do redakcii' zhurnalu 'Russkyj vestnyk'. Lystopad I858. S.-Peterburg” [“To the Editors of the Journal 'Russky Vestnik'. November I858. St. Petersburg”]. Shevchenko, T. Povne zibrannja tvoriv: u I2-ty tomah [Complete Works: in I2 vols.], vol. 6. Kiev, Naukova dumka Publ., 2003, pp. 222-223 (text), 534-537 (notes). (In Ukrainian) Zaslavs'kyj, I., Zaharkin, S. "Spogady Kesarja Bilylovs'kogo" ["Memoirs of Caesar Bilylovsky”]. Kyi'vs'ka starovyna, no. I, 2000, pp. I34-I54. (In Ukrainian) Il'nyc'kyj, M. "Pojedynok iz soboju: problema dvijnyctva v 'Pojedynku' I. Franka ta 'Dvijnyku' F. Dostojevs'kogo" [“Duel with Oneself: on the Duality in 'Duel' by I. Franko and 'The Double' by F. Dostoevsky”]. Slovo i Chas, no. 8, 2006, pp. I8-27. (In Ukrainian) 
Kostenko, N. “Tradycii' ukrai'ns'kogo baroko v tvorchosti Mykoly Bazhana” [“Traditions of Ukrainian Baroque in Mykola Bazhan's Works"]. Pytannja literaturoznavstva [Issues of Literary Studies], issue 3 (6o): Slov'jans'ki literatury [Slavic Literatures]. Chernivci, I996, pp. 36-45. (In Ukrainian) Drama-Esej [Executed Renaissance. Anthology I9I7-1933. Poetry-Prose-Drama-Essay]. Paryzh, Instytut Literacki Publ., I959. 980 p. (In Ukrainian) “Ot redaktsii. Iazyki samoopisaniia imperii i natsii kak issledovatel'skaia problema i politicheskaia dilemma” ["Editorial Note. Languages of Self-description of the Empire and the Nation as a Research Issue and a Political Dilemma”]. Ab Imperio, no. I, 2005, pp. II-22. (In Russ.) identychnosty [Anti-imperial Choice. The Rise of Ukrainian-Jewish Identity], authorized trans. from English by P. Grycak and M. Klymchuk, ed. by V. Dyvnych. Kiev, Krytyka Publ., 20I8. 432 p. (In Ukrainian)

I9 Selivanovs'kyj, O. "Kudy prjamuje Bazhan?” ["Where Is Bazhan Going?”]. Krytyka, no. 4, I931, pp. 39-47. (In Ukrainian)

20 Smolych, Ju. "Raja. Z 'Intymnoi' spovidi’.” [“Raya. From ‘Intimate Confession’.”]. Komentar, no. 3, 2004, p. I5. (In Ukrainian)

2I Suhomlynov, O. Etnokul'turnyj dyskurs $v$ literaturi pol's'ko-ukrai'ns'kogo pogranychchja XX stolittja [Ethnocultural Discourse in the Literature of Polish-Ukrainian Borderland of the $20^{\text {th }}$ Century]. Donec'k, LANDON-XXI Publ., 20I2. 376 p. (In Ukrainian) Franko, I. "Do istorii' ukrai'ns'kogo vertepu XVIII v." [“On the History of Ukrainian Vertep of the $\mathrm{I} 8^{\text {th }}$ Century"]. Zapysky Naukovogo tovarystva im. Shevchenka [Proceedings of the Shevchenko Academic Group], vol. LXXII. L'viv, I906, pp. I70-2IO. (In Ukrainian)

23 Cymbal, Ja. "Seks i kontekst" [“Sex and Context”]. Krytyka, part 5-6, 2009, pp. 31-33. (In Ukrainian)

24 Cymbal, Ja. “'Haj zhyve pryljudnyj pocilunok v golu grud’!': problemy vydannja ta komentuvannja pryvatnyh dokumentiv intymnogo harakteru” [“'Long Live the Public Kiss on the Bare Chest!': Issues of Publishing and Commenting on Private Documents of an Intimate Nature"]. Spadshhyna: Literaturne dzhereloznavstvo. Tekstologija [Heritage: Literary Source Studies. Textual Criticism], vol. 6. Kiev, Laurus Publ., 20II, pp. 65-87. (In Ukrainian)

25 Estraikh, Gennady J. In Harness: Yiddish Writer's Romance with Communism. Syracuse, Syracuse University Press, 2005. 224 p. (In English)

26 Löwis, Sabine von. "Phantom borders in the political geography of East Central Europe: an introduction.” Erdkunde. Archive for Scientific Geography, vol. 69, issue 2, 2015, pp. 99-I06. (In English) 